\title{
PENGARUH MASASE ENDORPHIN TERHADAP TINGKAT KECEMASAN DAN INVOLUSIO UTERI IBU NIFAS
}

\author{
Sri Rahayu ${ }^{1)}$ Melyana Nurul Widyawati ${ }^{2)}$ Retno Kusuma Dewi ${ }^{3)}$ \\ E-mail address: yayoek.1974@gmail.com
}

\begin{abstract}
One of factor in the failure of the breastfeeding process is maternal anxiety. Anxiety during breastfeeding will block the letdown reflex so that milk production decreases. The Efforts to reduce gold can be done with endorphin massage. Other benefits of breastfeeding more often will accelerate uterine involution. The aim of the study was to analyze the effect of endorphin massage on anxiety and the process of involuntary uterine maternal uterine.

This type of research is quasi-experimental with a pre-post test with control group design. The population is all normal postpartum mothers in District 1 and 2 District Health Centers in Grobogan District. The sample number of treatment group 13 and control group 13 was taken by simple random sampling. Data analysis with Independent t- test. For the control group, care was taken according to the standards in service, namely counseling for postpartum mothers on how to breastfeed, massage of uterine fundus.

The results of the study before treatment most of the respondents experienced moderate anxiety (69\%), and average fundal uteri height of $10.5 \mathrm{~cm}$. The independent $t$ test showed that there was an effect of endorphin massage on anxiety level ( $\mathrm{p}$ value $=0.001$ ) and there was no effect on uterine involution ( $\mathrm{p}$ value $=0.302$ ). Endorphin massage done by husbands to postpartum mothers contributes very well in reducing maternal anxiety, increasing self-confidence for the need to be socialized to the community, especially postpartum mothers and husbands to always be able to cooperate and support each other for the health and welfare of mothers and babies.

Keywords: endorphin massage; anxiety; involusio uteri

${ }^{122) 3)}$ Poltekkes Kemenkes Semarang

\section{Pendahuluan}

Angka Kematian Ibu (AKI) di Indonesia pada tahun 2015 menurut SUPAS sebesar 305/100.000 KH, angka ini masih tinggi dibanding target sebesar 102/100.000 KH. Di Jawa Tengah AKI pada tahun 2016 yaitu sebesar 109, 6/100.000 KH, angka ini sudah turun jauh dibandingkan pada

tahun sebelumnya, namun masih diatas target yang diharapakan. Penyebab kematian ibu di Jawa Tengah adalah perdarahan sebesar 33,2\% dan penyakit lain $21,6 \%$. Salah satu penyebab utama perdarahan postpartum adalah atonia uteri, yaitu kegagalan mekanisme akibat gangguan fungsi miometrium (Profil Kesehatan Jawa Tengah, 2016).
\end{abstract}


Upaya pencegahan perdarahan postpartum dapat dilakukan semenjak persalinan kala 3 dan 4 dengan pemberian oksitosin. Hormon oksitosin sangat berperan dalam proses involusio uterus. Proses involusio akan berjalan dengan baik jika kontraksi uterus kuat sehingga harus dilakukan tindakan untuk memperbaiki kontraksi uterus. Upaya untuk mengendalikan terjadinya perdarahan dari tempat plasenta dengan memperbaiki kontraksi dan retraksi serat miometrium sehingga merangsang pengeluaran oksitosin. Upaya lain untuk meningkatkan reflek okitosin dilakukan dengan menyusui sedini mungkin.

Ibu pada jam-jam pertama kelahiran masih merasakan lelah karena proses persalinannya, sehingga ibu masih fokus pada dirinya dan proses menyusui dapat tertunda, hal ini jika dibiarkan akan menghambat produksi ASI. Proses menyusui yang terhambat akan menyebabkan kurangnya reflek isapan pada bayi sehingga akan menghambat pula oksitosin keluar. Faktor lain yang mengambat keluarnya oksitosin adalah kecemasan ibu. Kecemasan merupakan kebingungan, kekhawatiran pada sesuatu yang akan terjadi dengan penyebab yang tidak jelas dan dihubungkan dengan perasaan tidak menentu dan tidak berdaya. Secara umum sebagian besar ibu mengalami gangguan emosional setelah melahirkan, bentuk gangguan postpartum yang umum adalah gangguan mood pada ibu postpartum baik primipara maupun multipara (Saleha, 2009). Kecemasan pada periode postnatal disebabkan karena adanya proses transisi menjadi orang tua, terjadi penyesuaian diri yang besar dalam beradaptasi dengan peran barunya. Selain hal tersebut faktor penyebab terjadinya kecemasan pada ibu post partum yakni perubahan hormone, payudara membengkak dan menyebabkan rasa sakit atau jahitan yang belum sembuh. Bila ibu mengalami kecemasan pada saat menyusui maka akan terjadi suatu blokade dari refleks let down. Ini disebabkan oleh karena adanya pelepasan dari adrenalin (epinefrin) yang menyebabkan vasokontraksi dari pembuluh darah alveoli, sehingga oksitosin sedikit harapannya untuk dapat mencapai target organ mioepitelium (Guyton \&Hill, 2016).

Masase merupakan salah satu cara untuk rileksasi pada ibu, karena sentuhan memiliki keajaiban tersendiri yang sangat berguna untuk menghilangkan rasa lelah pada tubuh, memperbaiki sirkulasi darah, merangsang tubuh untuk mengeluarkan racun, serta meningkatkan kesehatan pikiran. Teknik masase membantu ibu merasa lebih segar, rileks, dan nyaman. Hal itu terjadi karena masase merangsang tubuh melepaskan senyawa endorphin yang merupakan pereda sakit alami. Salah satu masase yang dapat diberikan kepada ibu adalah endorphin. Endorphin dapat menciptakan perasaan nyaman dan enak sehingga mengurangi kecemasan yang ibu rasakan. Endorfin Massage merupakan sebuah terapi sentuhan serta pijatan ringan. Hal ini disebabkan karena pijatan merangsang tubuh untuk melepaskan senyawa endorfin yang dapat menormalkan denyut jantung dan tekanan darah, mengurangi rasa sakit, mengendalikan perasaan stres dan menciptakan perasaan nyaman serta meningkatkan kondisi rileks dalam tubuh ibu dengan memicu perasaan nyaman melalui permukaan kulit. 
Terbukti dari hasil penelitian, teknik ini dapat meningkatkan pelepasan zat oksitosin, sebuah hormon yang memfasilitasi dalam proses pengeluaran ASI dan membantu proses pengecilan rahim pasca persalinan (Prasetyono, 2009). Proses pengeluaran ASI dapat memperbaiki involusi uteri.

Penelitian sebelumnya (Pamuji\&Rahayu, 2013) menyebutkan bahwa ada pengaruh pijat woolwhich dan endorphin terhadap peningkatan hormon prolaktin dan volume ASI. Hormon prolaktin atau reflek pengeluaran yang meningkat, salah satu penyebabnya adalah meningkatnya let down refleks yang memicu oksitosin, sehingga akan memberikan pengaruh positif pada proses involusio uteri. Penelitian lain oleh Aini, 2017 menyatakan ada pengaruh hipnobreastfeeding terhadap proses involusio uteri dan peningkatan hormon prolaktin. Faktor lain yang mempengaruhi proses involusi uteri selain oksitosin adalah laktasi, dimana rangsangan psikis merupakan refleks dari mata ibu ke otak, mengakibatkan oksitosin dihasilkan, sehingga ASI dapat dikeluarkan sehingga uterus menjadi semakin keras berkontraksi. Oksitosin menyebabkan terjadinya kontraksi dan retraksi otot uterin sehingga akan menekan pembuluh darah yang mengakibatkan berkurangnya suplai darah ke uterus. Ini membantu untuk mengurangi situs atau tempat implantasi plasenta serta mengurangi perdarahan (Suherni, 2008).

Tujuan penelitian ini adalah untuk menganalisis pengaruh masase endorphin terhadap kecemasan dan proses involusio uteri ibu nifas.

\section{Metode Penelitian}

Jenis penelitian ini adalah quasi experimental dengan rancangan prepost test with control group design.. Populasinya semua ibu nifas normal di Puskesmas Wilayah Gubug 1 dan 2 Kabupaten Grobogan. Jumlah sampel adanya kekawatiran terhadap hal-hal tertentu. Seseorang yang berada pada kondisi cemas akan mengganggu kemampuan individu untuk mencapai tujuan yang diinginkan. Kecemasan perlu mendapatkan perhatian supaya tidak berlarut-larut dan menimbulakn ketidaknyamanan bagi orang tersebut dan sekitarnya (Barlow, 2006). Kecemasan yang berlanjut pada ibu nifas dapat berpengaruh kurang baik terhadap produksi ASI. Ibu perlu mendapatkan suasana yang nyaman dan rileks selama proses menyusui.

Kelompok perlakuan adalah peneliti dibantu dibantu enumerator mengajarkan suami ibu nifas cara masase endorphin, dengan mengusap lembut bagian lengan dilanjutkan bagian punggung yang dilakukan selama 30 menit diwaktu pagi selama 5 hari, pijatan dimulai pada hari ke 3 post partum sampai hari ke 7 postpartum. Sebelum dan sesudah hari ke-7 dilakukan pengukuran kecemasan dengan Zung Self-Rating Anxiety Scale (ZSAS) dan involusio uteri dengan mengukur tinggi fundus uteri menggunakan metline. Analisa data dengan Independen $\mathrm{t}$ test. Untuk kelompok kontrol dilakukan asuhan sesuai standar yang ada dipelayanan yaitu konseling pada ibu nifas tentang cara menyusui, masase fundus uteri. 


\section{Hasil dan Pembahasan}

Tabel 1 dan 2 menunjukkan sebagian besar responden pada kelompok perlakuan dari 69\% yang mengalami kecemasan sedang, setelah adanya intervensi masase endorphin $61,5 \%$ tidak cemas. Kecemasan keadaan atau mood seseorang yang ditandai dengan ketegangan fisik dan adanya kekawatiran terhadap hal-hal tertentu. Seseorang yang berada pada kondisi cemas akan mengganggu

Tabel 3 menunjukkan proses involusio uteri pada kelompok perlakuan terjadi penurunan TFU menjadi $6,58 \mathrm{~cm}$, sedangkan pada kelompok kontrol penurunan TFU menjadi $7 \mathrm{~cm}$. Antara kelompok perlakuan dan kontrol terjadi rerata selisih penurunan TFU sebesar 0,54 $\mathrm{cm}$, lebih cepat pada kelompok perlakuan. Proses Involusio uteri dipengaruhi oleh banyak hal, salah satunya adalah kontraksi uterus. Proses involusi uterus terjadi karena adanya kontraksi dari moimetrium untuk mengemballikan uterus seperti sebelum hamil. Adanya hisapan bayi juga dapat merangsang keluarnya hormon oksitosin yang berguna untuk merangsang let down reflek yaitu memancarkan ASI dari duktus laktiferous dan proses involusi uterus. Selain itu dengan memberikan pijatan atau masase pada punggung ibu akan dapat memicu peningkatan letdown refleks sehingga oksitosin akan naik. Faktor-faktor lain yang mempengaruhi involusi uterus adalah umur, menyusui dini, paritas, jenis persalinan, mobilitas dini, dan kondisi psikologis ibu (Wignjosastro, 2009).
Tabel 1 : Analisa Deskriptif Tingkat

Kecemasan Ibu Nifas sebelum

perlakuan

\begin{tabular}{llll}
\hline $\begin{array}{l}\text { Kelompok } \\
\text { Sebelum }\end{array}$ & Tingkat & $\mathrm{n}$ & $\%$ \\
\hline Perlakuan & Cecemasan & & \\
& Cemas Singan & 4 & 30.7 \\
\multirow{3}{*}{ Kontrol } & Ceman Ringan & 9 & 69 \\
& Cemas Sedang & 11 & 84.6 \\
\hline
\end{tabular}

Tabel 2: Analisa Deskriptif Tingkat Kecemasan Ibu Nifas sesudah perlakuan

\begin{tabular}{l|l|l|l}
\hline $\begin{array}{l}\text { Kelompok } \\
\text { Sesudah }\end{array}$ & $\begin{array}{l}\text { Tingkat } \\
\text { Kecemasan }\end{array}$ & $\mathrm{n}$ & $\%$ \\
\hline Perlakuan & Tidak Cemas & 8 & 61.5 \\
& Cemas Ringan & 5 & 38.4 \\
Kontrol & Cemas Ringan & 9 & 69 \\
& Cemas Sedang & 4 & 30.7 \\
\hline
\end{tabular}

Tabel 1 dan 2 menunjukkan sebagian besar responden pada kelompok perlakuan dari 69\% yang mengalami kecemasan sedang, setelah adanya intervensi masase endorphin $61,5 \%$ tidak cemas. Kecemasan keadaan atau mood seseorang yang ditandai dengan ketegangan fisik dan adanya kekawatiran terhadap hal-hal tertentu. Seseorang yang berada pada kondisi cemas akan mengganggu kemampuan individu untuk mencapai tujuan yang diinginkan. Kecemasan perlu mendapatkan perhatian supaya tidak berlarut-larut dan menimbulakn ketidaknyamanan bagi orang tersebut dan sekitarnya (Barlow, 2006). Kecemasan yang berlanjut pada ibu nifas dapat berpengaruh kurang baik terhadap produksi ASI. Ibu perlu mendapatkan suasana yang nyaman dan rileks selama proses menyusui. 
Tabel 3: Analisis Deskriptif Involusio Uteri Ibu Nifas

\begin{tabular}{cccc}
\hline $\begin{array}{c}\text { Kelompok } \\
\text { Sebelum }\end{array}$ & $\begin{array}{c}\text { Involusio } \\
\text { Uteri } \\
\text { Mean } \pm \text { SD }\end{array}$ & $\begin{array}{c}\text { Kelompok } \\
\text { Sesudah }\end{array}$ & $\begin{array}{c}\text { Involusio } \\
\text { Uteri } \\
\text { Mean } \pm \text { SD }\end{array}$ \\
\hline Perlakuan & $10.5 \pm 0.51$ & Perlakuan & $6.58 \pm 0.8$ \\
\hline Kontrol & $10.38 \pm 0.65$ & Kontrol & $7 \pm 0.86$ \\
\hline
\end{tabular}
involusio uteri pada kelompok perlakuan terjadi penurunan TFU menjadi $6,58 \mathrm{~cm}$, sedangkan pada kelompok kontrol penurunan TFU menjadi $7 \mathrm{~cm}$. Antara kelompok perlakuan dan kontrol terjadi rerata selisih penurunan TFU sebesar 0,54 $\mathrm{cm}$, lebih cepat pada kelompok perlakuan. Proses Involusio uteri dipengaruhi oleh banyak hal, salah satunya adalah kontraksi uterus. Proses involusi uterus terjadi karena adanya kontraksi dari moimetrium untuk mengemballikan uterus seperti sebelum hamil. Adanya hisapan bayi juga dapat merangsang keluarnya hormon oksitosin yang berguna untuk merangsang let down reflek yaitu memancarkan ASI dari duktus laktiferous dan proses involusi uterus. Selain itu dengan memberikan pijatan atau masase pada punggung ibu akan dapat memicu peningkatan letdown refleks sehingga oksitosin akan naik. Faktor-faktor lain yang mempengaruhi involusi uterus adalah umur, menyusui dini, paritas, jenis persalinan, mobilitas dini, dan kondisi psikologis ibu (Wignjosastro, 2009).

Tabel 4. Uji homogenitas

\begin{tabular}{|c|c|c|c|}
\hline \multirow[t]{2}{*}{ Variabel } & \multicolumn{2}{|c|}{ Kelompok } & \multirow[t]{2}{*}{$p$} \\
\hline & $\begin{array}{c}\text { Masase } \\
\text { Endorphin } \\
(\text { Mean } \pm \text { SD) }\end{array}$ & $\begin{array}{c}\text { Kontrol } \\
(\text { Mean } \pm \text { SD })\end{array}$ & \\
\hline $\begin{array}{l}\text { Tingkat } \\
\text { Kecemasan }\end{array}$ & $65,4 \pm 1,85$ & $62,2 \pm 2,77$ & 0,662 \\
\hline $\begin{array}{l}\text { Involusio } \\
\text { Uteri }\end{array}$ & $10,5 \pm 0,51$ & $10,4 \pm 0,65$ & 1 \\
\hline
\end{tabular}

Hasil uji homogenitas pada variabel kecemasan dan involusio uteri nilai $p$ value> 0,05 sehingga kedua kelompok sebelum dilakukan perlakuan memiliki karakteristik yang sama.

Tabel 5 : Perbedaan Kecemasan dan Involusio Uteri pada Kedua Kelompok

\begin{tabular}{lccc}
\hline \multirow{2}{*}{ Variabel } & \multicolumn{2}{c}{ Kelompok } & $p$ \\
\cline { 2 - 3 } & $\begin{array}{c}\text { Masase } \\
\text { Endorphin } \\
\text { Mean } \pm \text { SD }\end{array}$ & $\begin{array}{c}\text { Kontrol } \\
\text { Mean } \pm \text { SD }\end{array}$ & \\
\hline Kecemasan & & & \\
Sebelum & $65,4 \pm 1,85$ & $62,2 \pm 2,77$ & \\
Sesudah & $59,9 \pm 1,75$ & $59,5 \pm 2,60$ & \\
$\Delta$ & & & 0,001 \\
\hline Invousio & & & \\
Uteri & $10,5 \pm 0,51$ & $10,4 \pm 0,65$ & \\
Sebelum & $6,85 \pm 0,801$ & $7,08 \pm 0,86$ & \\
Sesudah & & & 0,302 \\
$\Delta$ & & & \\
\hline
\end{tabular}

Pada tabel 5. menunjukkan adanya penurunan skor kecemasan pada ibu sebelum dan sesudah masase endorphin oleh suami dengan skor rerata dari 65,4 turun menjadi 59,9. Suami mempunyai peran yang sangat penting dalam mensuport ibu selama proses menyusui. Dukungan yang kuat akan meningkatkan rasa percaya diri ibu sehingga kecemasan akan berkurang bahkan menjadi tidak cemas. Zung menetapkan untuk tingkat kecemasan adalah ringan jika skor 45-59, sedang skor 60-74. Hasil uji stataitik menunjukkan ada perbedaan tingkat kecemasan ibu pada kelompok yang diberikan masase endorphin dan kelompok kontrol. Untuk involusio uteri hasil uji statistik menunjukkan tidak ada perbedaan antara kelompok yang diberikan masase endorphin dan kelompok kontrol, namun ukuran tinggi fundus uteri yang diukur dari tepi atas simpisis pada kelompok perlakuan $(6,85 \mathrm{~cm})$ lebih cepat turun dibandingkan 
kelompok kontrol (7,08). Involusio uteri merupakan proses pengembalian uterus ke kondisi sebelum hamil dengan berat kurang kebih 60 gram. Proses involusio dimulai segera segera setelah plasenta lahir akibat kontrkasi otot-otot polos uterus ditandai dengan penurunan tinggi fundus uteri $1 \mathrm{~cm}$ setiap harinya dan kontraksi uterus baik (Wignjosastro, 2009). Ibu nifas dianjurkan segera setelah bayi lahir menyusui bayinya, hisapan puting susu oleh bayi akan merangsang pelepasan oksitosin. Hormon oksitosin akan menyebabkan terjadinya kontraksi dan retraksi otot uterus sehingga akan menekan pembuluh darah yang menyebabkan suplai darah ke uterus. Penurunan uterus yang cepat dicerminkan oleh perubahan lokasi uterus, yang dapat dinilai dengan mengukur panjaang uterus dari arah simpisis menuju ke fundus uteri (Rullynil dkk, 2014). Alternatif lain yang bisa dilakukan untuk meningkatkan hormon oksitosin adalah dengan melakukan masase endorphin pada ibu nifas. Masase endorphin dapat diajarkan pada suami, sehingga peran serta suami akan sangat memberikan dukungan pada ibu.

Masase endorphin membantu ibu merasa lebih segar, rileks, dan nyaman pasca melahirkan (Sukmaningtyas, 2017). Hal itu terjadi karena masase merangsang tubuh melepaskan senyawa endorphine yang merupakan pereda sakit alami. Endorphine juga dapat menciptakan perasaan nyaman dan enak sehingga mengurangi kecemasan yang ibu rasakan. kecemasan ibu pasca persalinan dapat menghambat keluarnya colostrum, bahkan bisa juga berpengaruh terhadap pertumbuhan bayi. (Zanardo et al., 2001) Masase endorphine adalah sebuah terapi sentuhan atau pijatan ringan yang cukup penting diberikan pada wanita hamil maupun ibu pasca salin. Hal ini disebabkan karena pijatan merangsang tubuh untuk melepaskan senyawa endorphin yang merupakan pereda rasa sakit dan dapat menciptakan perasaan nyaman. $\beta$-Endorphin dapat menjadi prediktor awal yang berguna untuk gejala depresi postpartum. Pada ibu postpartum dengan depresi memiliki kadar $\beta$-endorphin yang lebih tinggi selama kehamilan dibandingkan dengan wanita tanpa gejala depresi. (Yim et al., 2010)

Selama ini endorphine sudah dikenal sebagai zat yang banyak manfaatnya. Beberapa diantaranya adalah mengatur produksi hormon pertumbuhan dan seks, mengendalikan rasa nyeri serta sakit yang menetap, mengendalikan perasaan stres, serta meningkatkan sistem kekebalan tubuh. Endorphine dalam tubuh bisa dipicu munculnya melalui berbagai kegiatan, seperti pernapasan yang dalam dan relaksasi, serta meditasi (Kuswandi, 2011, p 108). Pijatan yang diberikan pada ibu postpartum dapat memberikan rasa tenang dan nyaman pada masa menyusui sehingga meningkatkan respon hipofisis posterior untuk memproduksi hormon oksitosin yang dapat meningkatkan let down reflex dan produksi ASI. Penelitian terkait tentang masase diantaranya oleh Widyawati, 2016 menunjukkan ada pengaruh Loving masasse terhadap tingkat stress dan kadar hormon prolaktin ibu nifas primipara di Kota Semarang. Penelitian Rifan, 2017 menyatakan adanya pengaruh pemberian back rolling massage dan woolwich massage terhadap kecepatan ekskresi ASI pada ibu post partum 
dengan sectio caesarea. Kecemasan pada ibu pasca melahirkan dapat dikurangi dengan bounding atachment lebih awal (Lonstein, 2007)

\section{Simpulan}

Masase endorphin yang dilakukan oleh suami kepada ibu nifas memberikan kontribusi yang sangat baik dalam mengurangi kecemasan ibu, meningkatkan rasa percaya diri untuk itu perlunya disosialisasikan kepada masyarakat khususnya ibu nifas dan suami untuk selalu bisa bekerjasama dan saling mensuport untuk kesehatan dan kesejahteraan ibu dan bayinya.

Sebagai petugas kesehatan khususnya bidan perlu mengembangkan diri dan meningkatkan kompetensinya dengan memberikan asuhan kebidanan holistik kepada klien, salah satunya adalah kemampuan dalam mengelola kecemasan ibu post partum dengan masase endorphin.

\section{Daftar Pustaka}

Aini, Y.N., Hadi, H., Rahayu, S., Pramono, N. and Mulyantoro, D.K., 2017. effect of combination of oxytocin massage and hypnobreastfeeding on uterine involution and prolactin levels in postpartum mothers. Belitung Nursing Journal, 3(3), pp.213-220.

Barlow,

David.(2006).Intisari Psikologi Abnormal. Yogyakarta : Pustaka Pelajar

Guyton\&Hill (2016). Fisiologi Kedokteran, Edisi 12, Penerbit Saunder Elzeiver

Jateng. 2016. Profil Kesehatan Jawa
Tengah

Kuswandi, L. (2011) Keajaiban Hypno-Birthing. Jakarta: Pustaka Bunda.

Lonstein, J. S. (2007) 'Regulation of anxiety during the postpartum period', 28, pp. 115-141. doi: 10.1016/j.yfrne.2007.05.002.

Pamuji, S.E.B. and Rahayu, S., 2015. Pengaruh kombinasi metode pijat woolwich dan endorphine terhadap kadar hormon prolaktin dan volume asi (studi pada ibu postpartum di griya hamil sehat mejasem kabupaten tegal). Jurnal Ilmu dan Teknologi Kesehatan, 5(1).

Rif'an, A., 2017. Pemberian back rolling massage dan woolwich massage terhadap kecepatan ekskresi asi pada ibu post partum dengan sectio caesarea di rsud ambarawa. Karya Ilmiah S. 1 Ilmu Keperawatan

Rullynil, N.T., Ermawati, E. and Evareny, L., 2014. Pengaruh Senam Nifas terhadap Penurunan Tinggi Fundus Uteri pada Ibu Post Partum di RSUP DR. M. Djamil Padang. Jurnal Kesehatan Andalas, 3(3).

Saleha, S.(2009). Asuhan kebidanan pada masa nifas : Salemba Medika, JakartaSlameto. 2010. Belajar dan Faktor-Faktor Yangm Mempengaruhi. Jakarta: PT.Rineka Cipta.

Sukmaningtyas, W. and Windiarti, P.A., 2016. Efektivitas Endorphine Massage Terhadap Tingkat Kecemasan Ibu Bersalin Primipara. Bidan Prada: Jurnal Publikasi Kebidanan Akbid YLPP Purwokerto, 7(1). 
Suherni. 2008. Perawatan Masa Nifas.

Yogakarta: Fitramaya.

Widyawati, M.N., Hadisaputro, S., Anies, A. and Soejoenoes, A., 2016. Effect of Massage and Aromatherapy on Stress and Prolactin Level among Primiparous Puerperal Mothers In Semarang, Central Java, Indonesia. Belitung Nursing Journal, 2(4).

Prasetyono, D.S. 2009. ASI Eksklusif Pengenalan, Praktik dan Kemanfaatannya. Diva Press. Yogyakarta.

Wiknjosastro H. (2009). Ilmu Kebidanan. Edisi ke-4 Cetakan ke-2. Jakarta: Yayaan Bina. Pustaka Sarwono Prawirohardjo;

Yim, I. S. et al. (2010) 'Prenatal $\beta$ endorphin as an early predictor of postpartum depressive symptoms in euthymic women', Journal of Affective Disorders. Elsevier B.V., 125(1-3), pp. 128-133. doi: 10.1016/j.jad.2009.12.009.

Zanardo, V. et al. (2001) 'Effect of postpartum anxiety on the colostrol milk g-endorphin concentrations of breastfeeding mothers', Journal of Obstetrics \& Gynaecology, 21(2), pp. 130-134. 